\title{
Upper Cenomanian - Lower Turonian (Cretaceous) calcareous algae from the Eastern Desert of Egypt: taxonomy and significance
}

\author{
Ioan I. BUCUR¹, Emad NAGM² \& Markus WILMSEN³ \\ ${ }^{1}$ Department of Geology, “Babeş-Bolyai” University, Kogălniceanu 1, 400084 Cluj Napoca, Romania \\ ${ }^{2}$ Geology Department, Faculty of Science, Al-Azhar University, Egypt \\ ${ }^{3}$ Senckenberg Naturhistorische Sammlungen Dresden, Museum für Mineralogie und Geologie, Sektion Paläozoologie, \\ Königsbrücker Landstr. 159, D-01109 Dresden, Germany
}

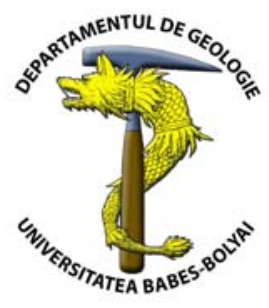

\begin{abstract}
An assemblage of calcareous algae (dasycladaleans and halimedaceans) is described from the Upper Cenomanian to Lower Turonian of the Galala and Maghra el Hadida formations (Wadi Araba, northern Eastern Desert, Egypt). The following taxa have been identified: Dissocladella sp., Neomeris mokragorensis RADOIČIĆ \& SCHLAGINTWEIT, 2007, Salpingoporella milovanovici RADOIČIĆ, 1978, Trinocladus divnae RADOIČIĆ, 2006, Trinocladus cf. radoicicae ELLIOTT, 1968, and Halimeda cf. elliotti CONARD \& RIOULT, 1977. Most of the species are recorded for the first time from Egypt. Three of the identified algae ( $T$. divnae, S. milovanovici and $H$. elliotti) also occur in Cenomanian limestones of the Mirdita zone, Serbia, suggesting a trans-Tethyan distribution of these taxa during the early Late Cretaceous. The abundance and preservation of the algae suggest an autochthonous occurrence which can be used to characterize the depositional environment. The recorded calcareous algae as well as the sedimentologic and palaeontologic context of the Galala Formation support an open-lagoonal (non-restricted), warm-water setting. The Maghra el Hadida Formation was mainly deposited in a somewhat deeper, open shelf setting. Calcareous algae (Halimeda cf. elliotti CONARD \& RIOULT) are restricted to one level in the uppermost Lower Turonian which indicates a brief return to shallow-water deposition after a significant deepening with maximum flooding during the early Early Turonian.
\end{abstract}

Keywords: Cretaceous, dasycladalean and halimedacean algae, palaeontological description, environmental significance, Egypt.

\section{INTRODUCTION}

Fossiliferous Upper Cretaceous successions are well exposed in the northeastern part of Egypt (Fig. 1). The strata are represented by marine siliciclastics, mixed with carbonates or interfingering with pure limestones at many localities in the northern Eastern Desert (Kuss, 1986a; Nagm, 2009) and Sinai (Kuss, 1989; Bauer et al., 2001, 2002, 2003).

In contrast to other fossil groups such as ammonoids which are fairly well studied (e.g., Luger and Gröschke, 1989; Kassab, 1991; Aly and Abdel-Gawad, 2001; Hewaidy et al., 2003; Nagm et al., submitted), few studies have been published on Upper Cretaceous calcareous algae of Egypt (Kuss, 1986b; Kuss and Conrad, 1991; Bauer et al., 2002). These works resulted in the identification of ca. 24 taxa of calcareous algae from different levels within the Cretaceous succession of the Eastern Desert and the Sinai Peninsula (Table 1).

In the present paper we describe for the first time calcareous algae from Upper Cenomanian - Lower Turonian strata of western Wadi Araba, specifically the East Wadi *Correspondence: I.I. Bucur (ioan.bucur@ubbcluj.ro)
Ghonima section located in the western part of the north Eastern Desert (Fig. 1). The palaeoenvironmental and palaeobiogeographic significances of the records are briefly discussed.

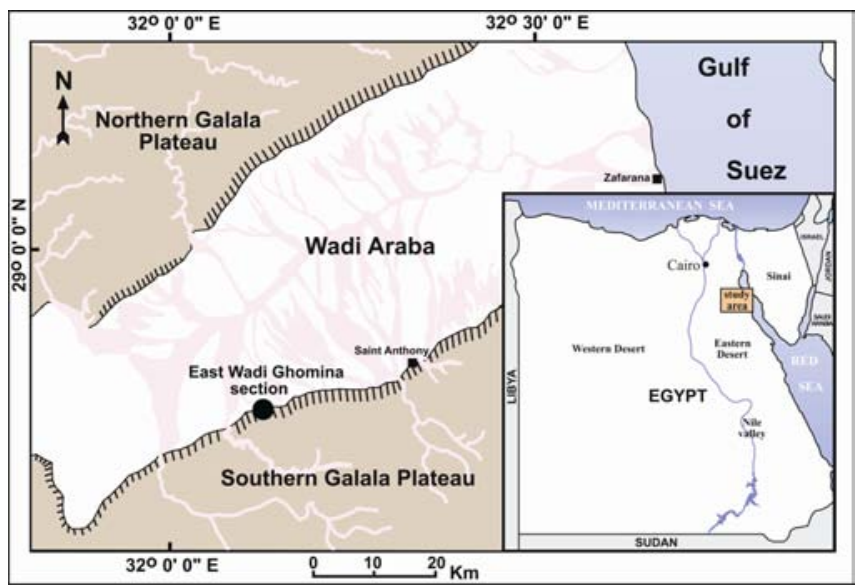

Fig. 1. Locality map of the study area in Egypt, indicating the position of the East Wadi Ghonima section (see Fig. 2). 


\section{GEOLOGICAL SETTING}

The Wadi Araba is bounded in the north and south by the Galala plateaux and in the east by the Gulf of Suez (Fig. 1). It is about $30 \mathrm{~km}$ wide and extends westward to the central Eocene limestone plateau of the Egyptian Eastern Desert. Wadi Araba has a NE-SW trend, following the direction of a regional Syrian Arc anticline structure, which is one of the best-kwon structural features in the north of Egypt (Said, 1990). The Syrian Arc can be traced from Syria to the central Western Desert of Egypt, via Sinai and the northern part of the Eastern Desert. The Galala plateaux, representing a major branch of the Syrian Arc in the Eastern Desert, are characterized by Late Cretaceous uplift in the north and subsidence further to the south. Folding and/or uplift of the Syrian Arc began in post-Cenomanian times (Aal and Lelek, 1994) and reached its acme during the Late Cretaceous (Kuss et al., 2000). Palaeogeographically, Egypt was situated at the southern margin of the Neotethys Ocean during the Cretaceous, at ca. $5^{\circ}$ northern palaeo-latitude (Philip and Floquet, 2000) and deposition took place in tropical neritic settings. The early Late Cretaceous probably represents the most pronounced Cretaceous transgression in northern Egypt, with maximum flooding during the Early Turonian (e.g., Sharland et al., 2001; Nagm, 2009), and shallow marine Cenomanian - Turonian deposits are thus very widespread.

The East Wadi Ghonima section is located at the northern slope of the southern Galala Plateau (N 28 $51^{\circ}$ $34^{\prime \prime}$ E $\left.32^{\circ} 09^{\prime} 25^{\prime \prime}\right)$. At this locality, the most complete upper Middle Cenomanian - Turonian succession in the western Wadi Araba with a total thickness of $215 \mathrm{~m}$ is exposed (Fig. 2). It has a very good ammonoid record and serves as a standard section for the study area (Nagm, 2009). The succession commences with a non-marine sandstone unit (Malha Formation), followed unconformably by the Cenomanian Galala Formation. The Galala Formation reaches $95 \mathrm{~m}$ in thickness and is characterized by shallowmarine, open lagoonal deposits, comprising silty marls, marls, oyster shell beds and nodular fossiliferous limestones (Nagm, 2009; Fig. 2). The Galala Formation contains three horizons of calcareous algae (Fig. 2; 080217-3, 17-6, and 17-16), which can be dated as early Late Cenomanian (Neolobites vibrayeanus Zone; Nagm, 2009; Nagm et al., submitted). The upper limit of the Galala Formation is marked by a major unconformity at the base of the overlying Maghra El Hadida Formation. The measured thickness of the Maghra El Hadida Formation is about $118 \mathrm{~m}$. This formation starts with the Wadi Ghonima Member, consisting of a brown, fine- to medium-grained calcareous sandstone unit (Nagm, 2009). The succeeding succession of the Maghra El Hadida Formation is characterized by an increase in carbonate content, represented by yellow, soft marls intercalated with fine-grained wacke- to packstones containing a highly diverse upper Upper Cenomanian to Lower Turonian ammonite assemblage. At the summit of the Lower Turonian, within the upper Wrightoceras munieri Zone (Nagm, 2009; Nagm et al., submitted), another horizon rich in calcareous algae was encountered (080217-29). The Middle Turonian part of the Maghra El Hadida Formation consists of poorly fossiliferous, thick-bedded, yellowish marls, punctuated by occasionally intercalated, medium- to coarse-grained, hummocky cross-stratified sandstone beds. The upper part of the Maghra El Hadida Formation consists of fossiliferous marly limestones with Upper Turonian ammonites (Nagm, 2009; Nagm et al., submitted).

The samples 080217-3, 17-6 and 17-16 from the Galala Formation are bioturbated skeletal wacke- to packstones. Recrystallized mollusc fragments (gastropods and bivalves) are most common, followed by dasycladalean and udoteacean algae as well as echinoderm debris, rare ostracod shells, serpulid tubes and small (?Gavelinella-like) foraminifera. Sample 17-16 contains rare foraminifera doubtfully ascribed to the genus Pseudorhipidionina. The fabric is inhomogeneous and the proportion of components is variable due to bioturbation.

Sample 080217-29 from the Maghra el Hadida Formation is a Halimeda wackestone. The udoteacean thalli are up to $5 \mathrm{~mm}$ long and float in a muddy-peloidal matrix. They are associated by fragments of gastropods, bivalves, echinoderms, worm tubes and ostracods (in decreasing importance). Foraminifera have not been observed. The inhomogenous fabric suggests bioturbation.

\section{SHORT DESCRIPTION OF THE ALGAE}

The first report of calcareous algae in Cretaceous deposits from Egypt was given by Kuss (1986b) who described dasycladaleans, udoteaceans and rhodophyceans from the Eastern Desert. Further records of calcareous algae from northeastern Egypt and southern Jordan have been published by Kuss and Conrad (1991) and Kuss (1994).

The calcareous algae described in this paper consist of the following taxa of dasycladalean and halimedacean green algae: Dissocladella sp., Neomeris mokragorensis RADOIČIĆ \& SCHLAGINTWEIT, 2007, Salpingoporella milovanovici RADOIČIĆ, 1978, Trinocladus divnae RADOIČIĆ, 2006, Trinocladus cf. radoicicae ELLIOTT, 1968, and Halimeda cf. elliotti CONARD \& RIOULT, 1977. Almost all of the taxa of this assemblage are reported for the first time from Egypt. Among the dasycladaleans, only $S$. milovanovici was doubtfully recorded (as Salpingoporella $\mathrm{cf}$. milanovici RADOIČIĆ, 1978) by Kuss and Conrad, 1991, p. 875, Fig. 4.16).

\section{Neomeris mokragorensis RADOIČIĆ \&} SCHLAGINTWEIT, 2007

Pl. I, Figs. 1-4.

?1986b-Neomeris cretacea - Kuss, p. 228, Fig. 5 d.

2007 - Neomeris mokragorensis sp. nov. - Radoičić and Schlagintweit, 2007, p. 43, Pl. 1, Figs. 1-12; Pl. 2, Figs. 1-3; Pl. 3, Figs. 1-6. [Late Albian-Santonian, with synonymy].

Dimensions:

$\mathrm{D}($ external diameter $)=1.1-1.65 \mathrm{~mm}$

$\mathrm{d}$ (diameter of the axial cavity) $=0.8-1.05 \mathrm{~mm}$

$\mathrm{d} / \mathrm{D}=0.64-0.73$

$\mathrm{w}$ (number of ampullae per verticil) $=25$

Diameter of ampullae $=0.10 / 0.12$ to $0.17 / 0.20 \mathrm{~mm}$

These dimensions fit well into the dimensional range given for the species by Radoičić and Schlagintweit (2007).

Discussion: Neomeris mokragorensis is characterized by calcification related mostly to the fertile, spheroidal ampullae. Plate I, Fig. 1 illustrates a strongly calcified specimen, but the subsphaerical ampullae indicate $N$. mokragorensis. The transverse and longitudinaloblique sections in Plate I, Fig. 2 and 3, respectively 
are more characteristic for the species. Figure 2 in Plate I shows a specimen with sparitic internal molds of the ampullae, while in Fig. 3 the ampullae have a thin sparitic sheath, the internal part being filled with micritic sediment.
Local occurrence: Lower Upper Cenomanian of the Galala Formation (sample 080217-3 and -17-6). Stratigraphical range: Late Albian-Santonian (Late Albian-Turonian of Serbia; Late Turonian-Late Santonian of the Northern Calcareous Alps; Radoičić and Schlagintweit, 2007).

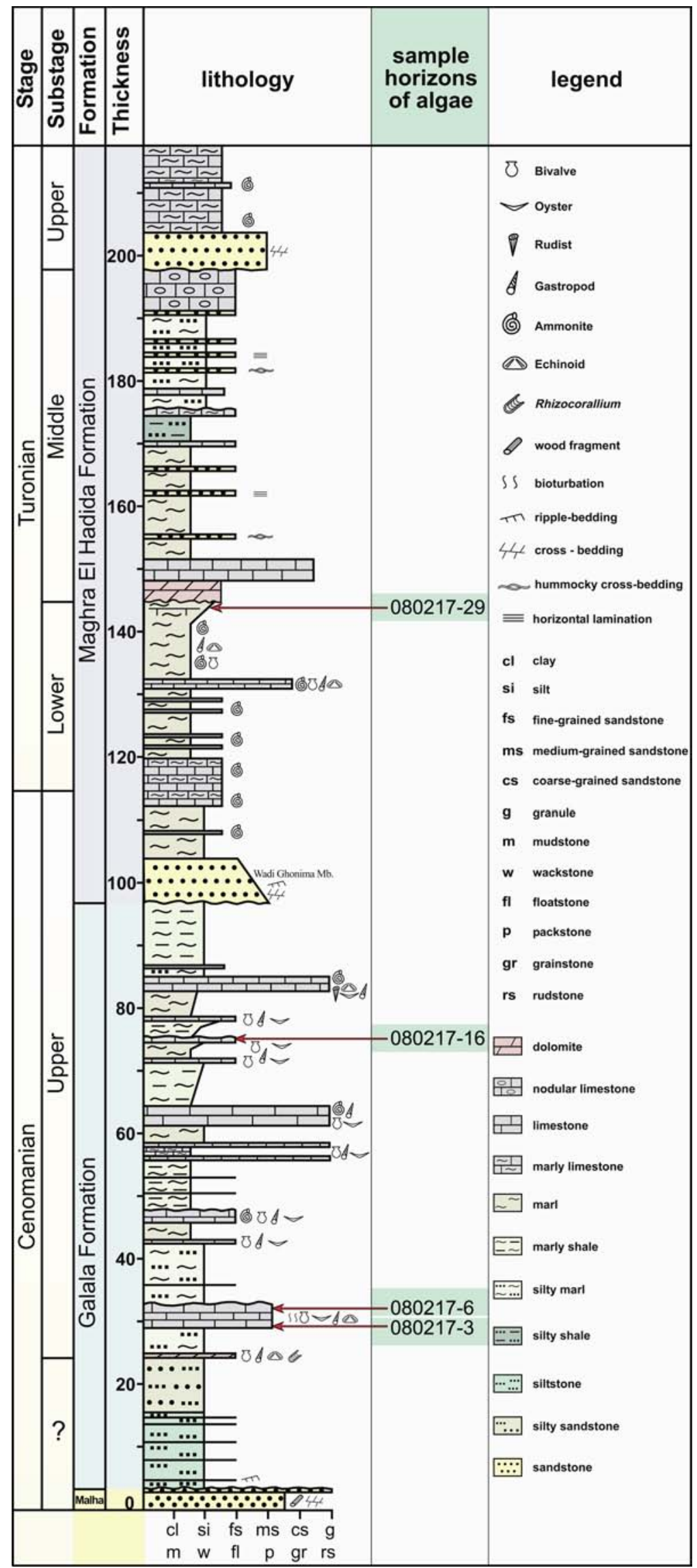

Fig. 2. Stratigraphic log of the East Wadi Ghonima section, showing the sample horizons of the calcareous algae. 
Table 1. Previously identified Cretaceous calcareous algae from Egypt $(\mathrm{Al} .=$ Albian; Ce. $=$ Cenomanian; $\mathrm{T} .=$ Turonian; Co. $=$ Coniacian; S. $=$ Santonian; Ca. = Campanian; Ma. = Maastrichtian; E.D. $=$ Eastern Desert.

\begin{tabular}{|c|c|c|c|c|c|c|c|c|c|c|}
\hline \multirow{2}{*}{ Calcarous algae } & \multicolumn{7}{|c|}{ Cretaceous Stages } & \multicolumn{2}{|c|}{ locality } & \multirow{2}{*}{ recorded by } \\
\hline & Al. & $\mathrm{Ce}$. & $\mathrm{T}$. & Co. & S. & Ca. & M. & E. D. & Sinai & \\
\hline Clypeina sp. & ! & - & & & & & & & - & \multirow{4}{*}{ Kuss and Conrad, 1991} \\
\hline Cylindroporella aff. C. barnesii & - & & & & & & & & - & \\
\hline Cylindroporella parva & & - & & & & & & - & & \\
\hline Cylindroporella sugdeni & - & & & & & & & & - & \\
\hline Trinocladus tripolitanus & & - & - & & & & & - & & \multirow{2}{*}{$\begin{array}{l}\text { Kuss, 1986b; Kuss and } \\
\text { Conrad, } 1991\end{array}$} \\
\hline Dissocladella undulata & & - & - & घ & & ! & & - & & \\
\hline Neomeris cretacea & - & - & - & & & & & - & - & $\begin{array}{c}\text { Kuss and Conrad, 1991; } \\
\text { Bauer et al., } 2002\end{array}$ \\
\hline Praturlonella haттиdai & & - & & & & & & - & & \multirow{4}{*}{ Kuss and Conrad, 1991} \\
\hline Salpingoporella dinarica & - & - & & & & & & & - & \\
\hline $\begin{array}{l}\text { Salpingoporella cf. milanovici } \\
\text { (sic!) }\end{array}$ & & - & & & & & & & - & \\
\hline Suppiluliumaella aff. S. schroederi & & - & & & & & & & - & \\
\hline Griphoporella sp. & & - & - & & & & & - & & Kuss, 1986b \\
\hline Acicularia sp. & & - & - & & & & & - & - & \multirow{2}{*}{$\begin{array}{l}\text { Kuss, } 1986 \mathrm{~b} \text {; Bauer et } \\
\text { al., } 2002\end{array}$} \\
\hline Bouenia pygmaea & & - & - & & & ! & - & - & - & \\
\hline Bouenia cf. hochstetteri & & & - & & & & & & - & Bauer et al., 2002 \\
\hline Halimeda sp. & & - & - & & & & & - & - & \multirow{3}{*}{ Kuss and Conrad, 1991} \\
\hline Permocalculus budaensis & & & - & & & & & & - & \\
\hline Permocalculus irenae & & - & & & & & & & - & \\
\hline Pseudochaetetes sp. & & - & - & & & & & - & & Kuss, 1986b \\
\hline Parachaetetes asvapatii & & & & & & - & - & - & & $\begin{array}{l}\text { Kuss, 1986b; Kuss and } \\
\text { Conrad, } 1991\end{array}$ \\
\hline $\begin{array}{l}\text { Parachaetetes } \mathrm{cf.} P . \\
\text { hadhramautensis }\end{array}$ & - & & & & & & & & - & Kuss and Conrad, 1991 \\
\hline Pseudolithothamnium album & & & & & & - & - & - & & Kuss, 1986b \\
\hline Arabicodium aegagrapiloides & & & - & & & & & & - & \multirow{2}{*}{ Bauer et al., 2002} \\
\hline Marinella lugeoni & & & - & & & & & & - & \\
\hline
\end{tabular}

Trinocladus divnae RADOIČIĆ, 2006

P1. I, Figs. 5, 7, 8, 10.

2006 - Trinocladus divnae sp. nov. - Radoičić, p. 66, textFig. 2, P1. 1, P1. 2, Figs. 1-8, P1. 3, Figs. 1-6, 10-11.

Dimensions:

$\mathrm{D}=0.66-1.2 \mathrm{~mm}$

$\mathrm{d}=0.18-0.21 \mathrm{~mm}$

$\mathrm{w}$ (number of primary laterals per verticil) $=$ aprox. 6-7

Discussion: The specimens from Egypt show the same general states of preservation as the specimens from Serbia. The outline of the main stem is visible in only one small specimen (Pl. I, Fig. 5, lower right corner). Other specimens (e.g., P1. I, Fig. 7) show the characteristic calcification of cup-like units of laterals. Larger specimens have a calcification reduced to the distal part of secondaries, and to the tertiary laterals (Pl. I, Fig. 5, lower left and upper part; P1. I, Fig. 10). Eventually, some specimens are almost completely recrystallized, displaying only the terminations of the tertiary laterals.

Local occurrence: Lower Upper Cenomanian of the Galala Formation (sample 080217-6 and 17-16).

Stratigraphic range: The type specimens are from the Albian-Cenomanian (Radoičić, 2006).

\section{Trinocladus sp. cf. T. radoicicae ELLIOTT, 1968}

P1. II, Fig. 3.

A single specimen in sample 080217-16 shows characteristic features which are close to Trinocladus radoicicae (Elliott, 1968): small thallus $(\mathrm{D}=0.65 \mathrm{~mm}$; $\mathrm{d}=$ $0.25 \mathrm{~mm}$ ) with primary laterals swelling out markedly before giving rise to thinner secondaries and tertiaries. The type specimens were described from Maastrichtian of Iraqi Kurdistan. The poor state of preservation of the Egyptian specimen from the lower Upper Cenomanian of the Galala Studia UBB, Geologia, 2010, 55 (1), 29 - 36
Formation, as well as the different geological age, makes this attribution uncertain.

\section{Dissocladella $\mathrm{sp.}$}

P1. II, Fig. 4.

Small specimen $(\mathrm{D}=0.40 ; \mathrm{d}=0.22)$ with pear-like primary laterals giving rise to a bush of small vesiculiform secondary laterals. It is recorded from the lower Upper Cenomanian of the Galala Formation (080217-16).

\section{Salpingoporella milovanovici RADOIČIĆ, 1978}

P1. II, Figs. 1-2.

1978 - Salpingoporella milovanovici n. sp. - Radoičić, p. 379, P1. 1-3, Cenomanian

?1991 - ? Salpingoporella cf. Salpingoporella milanovici Radoičić (sic!) - Kuss and Conrad, p. 876, Fig. 4.16.

1998 - Salpingoporella milovanovici RADOIČIĆ - Sgrosso et al., 1998, p. 113-115, Pl. 1, 2.

1999 - Salpingoporella milovanovici RADOIČIĆ - Masse and Arnaud-Vanneau, p. 63, P1. 1, Figs. 13, 14.

Dimensions:

$\mathrm{L}$ (maximum observed length) $=3.10 \mathrm{~mm}$

$\mathrm{D}=0.26-0.28 \mathrm{~mm}$

$\mathrm{d}=0.08-0.09 \mathrm{~mm}$

$\mathrm{h}$ (distance between consecutive verticils $)=0.07 \mathrm{~mm}$ 1 (length of primary laterals) $=0.08-0.09 \mathrm{~mm}$

$\mathrm{p}$ (diameter of primary laterals, distal part $)=0.06-0.08 \mathrm{~mm}$ Discussion: A good longitudinal, slightly oblique section was found (Pl. 2, Fig. 1), together with another smaller fragment (P1. 2, Fig. 2) in sample 080217-16. Salpingoporella milovanovici has small dimensions and this, together with an advanced recrystallization, could be why this species is frequently overlooked (Sgrosso et al., 1998), especially in thin sections having other larger dasycladaleans. 
Local occurrence: Lower Upper Cenomanian of the Galala Formation.

Stratigraphical range: Cenomanian of the Dinarids (Serbia, Montenegro, Hercegovina) and the Apennines (Radoičić, 1978; Sgrosso et al., 1998); Albian of the West Pacific (Masse and Arnaud-Vanneau, 1999).

\section{Halimeda sp. cf. Halimeda elliotti CONARD \& RIOULT, 1977}

Pl. II, Figs. 5-8.

Dimensions:

Length of segments (maximum) $=4.5 \mathrm{~mm}$

External diameter of the segments $=0.25-0.65 \mathrm{~mm}$

Diameter of the medullary zone $-0.09-0.20 \mathrm{~mm}$

Diameter of the medullary filaments $=0.030-0.040 \mathrm{~mm}$

Diameter of the cortical filaments $-0.015-0.018 \mathrm{~mm}$

Discussion: Numerous fragments of a halimedacen alga were identified in thin section 080217-29. They resemble Halimeda elliotti by the less calcified (darker) medullary zone and the more calcified (sparitic) cortical zone. However, some characteristics differentiate these specimens from the type species: the medullary zone is thinner than to the cortical one, and the segments are longer than most segments illustrated by Conard and Rioult (1977). Thus, the taxon is kept in open nomenclature.

Local occurrence: Upper Lower Turonian of the Maghra el Hadida Formation.

Stratigraphical range: Halimeda elliotti is known from the Cenomanian-Turonian (Conard and Rioult, 1977; Radoičić, 2006).

\section{CONCLUSION}

An assemblage of calcareous algae (dasycladaleans and halimedaceans) is described from Upper Cenomanian to Lower Turonian limestones of the Galala and Maghra el Hadida formations from the western part of the Wadi Araba, northern Eastern Desert, Egypt. The following taxa have been identified: Dissocladella sp., Neomeris mokragorensis RADOIČIĆ \& SCHLAGINTWEIT, 2007, Salpingoporella milovanovici RADOIČIĆ, 1978, Trinocladus divnae RADOIČIĆ, 2006, Trinocladus cf. radoicicae ELLIOTT, 1968, and Halimeda cf. elliotii CONARD \& RIOULT, 1977. Most of the species are recorded for the first time from Egypt, and were only recently described in the literature (e.g., Radoičić, 2006; Radoičić and Schlagintweit, 2007). It is interesting to note that three of the identified algae (T. divnae, S. milovanovici and H. elliotti) have also been found to be associated in the Cenomanian limestones from the Mirdita zone, Serbia (Radoičić, 2006), indicating a trans-Tethyan distribution of these taxa during the early Late Cretaceous. However, in the Mirdita zone, Radoičić (2006) found, together with Trinocladus divnae, the following foraminifera: Cuneolina, Nezzazatinella, Pseudolituonella reicheli, Chrysalidina gradata, Cisalveolina fraasi. Of these taxa, only $P$. reicheli has been recorded from the Galala Formation of the Wadi Ghonima area (Nagm, 2009). Thus, similarities in biofacies of our samples and the Mirdita zone are mainly related to the occurrences of calcareous algae. The abundance and preservation of dasycladaleans and halimedaceans in theese samples suggest that their occurrence is autochthonous. Thus, their presence can be used for the characterization of the depositional environment. Theese calcareous green algae indicate very shallow, light-saturated, warm-water settings (e.g., Wray 1977; Bucur and Săsăran, 2005).

The sedimentologic and palaeontologic context of the strata support an open-lagoonal (non-restricted) deposition for the Galala Formation (Nagm, 2009). The Maghra el Hadida Formation was mainly deposited in somewhat deeper, open shelf setting unsuitable for benthic algae dependent on light saturation. However, the occurrence of the Halimeda cf. elliotti is restricted to sediments that accumulated during the latest highstand of a Late Cenomanian - Early Turonian depositional sequence, just below a terminal emergence surface (Nagm, 2009). Thus, their presence in uppermost Lower Turonian strata indicates a brief return to shallow-water deposition after a significant deepening with maximum flooding during the early Early Turonian.

Acknowledgments. We thank reviewers F. Schlagintweit and R. Riding for their remarks, which improved the manuscript.

\section{R E F E R E N C E S}

Aal, A., Lelek, J. 1994, Structural development of the northern Sinai, Egypt and its implications on the hydrocarbon prospectivity of the Mesozoic. GeoArabia, 1: $15-30$.

Aly, M.F., Abdel-Gawad, G.I. 2001, Upper Cenomanian Lower Turonian ammonites from north and central Sinai, Egypt. El-Minia Science Bulletin, 13 (2) - 14 (1): 17-60.

Bauer, J., Kuss, J. \& Steuber, T. 2002, Platform environments, microfacies and systems tracts of the Upper Cenomanian-Lower Santonian of Sinai, Egypt. Facies, 47: 1-25.

Bauer, J., Kuss, J., \& Steuber, T. 2003, Sequence architecture and carbonate platform configuration (Late Cenomanian-Santonian), Sinai, Egypt. Sedimentology, 50: 387-414.

Bauer, J., Marzouk, A.M., Steuber, T. \& Kuss, J. 2001, Lithostratigraphy and biostratigraphy of CenomanianSantonian strata of Sinai, Egypt. Cretaceous Research, 22: 497-526.

Bucur, I.I., Săsăran, E. 2005, Relationship between algae and environment: an Early Cretaceous case study, Romania. Facies, 51: 274-286.

Conard, M., Rioult, M. 1977, Halimeda elliotti nov. sp., algue calcaire (Chlorophyceae) du Turonien des Alpes Maritimes (SE France). Géologie Méditerranéenne, 4 (2): 83-98.

Elliott, G.F. 1968, Permian to Paleocene calcareous algae (Dasycladaceae) of the Middle East. Bulletin of the British Museum (Natural History), Geology, Supplement 4: 1-111.

Hewaidy, A.A., Azab, M.M. \& Farouk, S. 2003, Ammonite biostratigraphy of the upper Cretaceous succession in the area West of Wadi Araba, North Eastern Desert, Egypt. Egyptian Journal of Paleontology, 3: 331-359.

Kassab, A.S. 1991, Cenomanian - Coniacian biostratigraphy of the northern Eastern Desert, Egypt, based on ammonites. Newsletters on Stratigraphy, 25: 25-35. 
Kuss, J. 1986a, Facies development of Upper CretaceousLower Tertiary sediments from the monastery of St. Anthony/Eastern Desert, Egypt. Facies, 15: 250-268.

Kuss, J. 1986b, Upper Cretaceous calcareous algae from the Eastern Desert of Egypt. Neues Jahrbuch für Geologie und Paläontologie, Monatshefte, p. 223-238.

Kuss, J. 1989, Facies and paleogeographic importance of the pre-rift limestone from NE-Egypt/Sinai. Geologische Rundschau, 78 (2): 487-498.

Kuss, J. 1991, Cretaceous (Albian-Turonian) calcareous algae from Egypt and Jordan - systematics, stratigraphy and paleogeography. Abhandlungen der Geologischen Bundesanstalt, 50: 295-317.

Kuss, J., Conrad, M.-A. 1991, Calcareous algae from Cretaceous carbonates of Egypt, Sinai, and Southern Jordan. Journal of Paleontology, 65: 869-882.

Kuss, J., Scheibner, C. \& Gietl, R. 2000, Carbonate platform to basin transition along an Upper Cretaceous to Lower Tertiary Syrian arc uplift, Galala plateaus, Eastern Desert, Egypt. GeoArabia, 5 (3): 405-424.

Luger, P., Gröschke, M. 1989, Late Cretaceous ammonites from the Wadi Qena area in the Egyptian Eastern Desert. Palaeontology, 32 (2 ): 355-407.

Masse, J.-P., Arnaud-Vanneau, A. 1999, Early Cretaceous calcareous algae of the mid-Pacific Mountains. Revue de Micropaléontologie, 42 (1): 57-69.

Nagm, E. 2009, Integrated stratigraphy, palaeontology and facies analysis of the Cenomanian -Turonian (Upper Cretaceous) Galala and Maghra el Hadida formations of the western Wadi Araba, Eastern Desert, Egypt. PhD thesis, Würzburg University, 213 p. (http://www.opusbayern.de/uni-wuerzburg/volltexte/2009/3988/).

Nagm, E., Wilmsen, M., Aly, M. \& Hewaidy, A. submitted, Cenomanian - Turonian (Cretaceous) ammonoids from the western Wadi Araba area, Eastern Desert, Egypt. Cretaceous Research.
Philip, J., Floquet, M. 2000, Late Cenomanian (94.7-93.5). In Atlas Peri-Tethys Palaeogeographical Maps (Dercourt et al., Eds.), CCGM/CGMW, p. 129-136.

Radoičić, R., Schlagintweit, F. 2007, Neomeris mokragorensis sp. nov. (calcareous alga, Dasycladales) from the Cretaceous of Serbia, Montenegro and the Northern Calcareous Alps (Gosau Group, Austria). Annales Géologiques de la Péninsule Balkanique, 68: 39-51.

Radoičić, R. 1978, Salpingoporella milovanovici, n. sp. A new dasyclad from the Cenomanian strata of the Dinarides, and a note on the foraminifer Nummoloculina sp. (aff. regularis Philippson). Annales Géologiques de la Péninsule Balkanique, 42: 375-381

Radoičić, R. 2006, Trinocladus divnae and Montiella filipovici - a new species (Dasycladales, green algae) from the Upper Cretaceous of the Mountain Paštrik (Mirdita zone). Annales Géologiques de la Péninsule Balkanique, 67: 65-87.

Said, R. 1990, The geology of Egypt. Balkema, Rotterdam, $721 \mathrm{p}$.

Sgrosso, A., Esposito, P. \& Radoičić, R. 1998, The occurrence of Salpingoporella milovanovici Radoičić (Dasycladales) in the Cenomanian of south Apennines and Dinarides. Geologija, 40: 113-117.

Sharland, P.R., Archer, R., Casey, D.M., Davies, R.B., Hall, S.H., Heward, A.P., Horbury, A.D. \& Simmons, M.D. 2001, Arabian plate sequence stratigraphy. GeoArabia Special Publication, 2, 371 p.

Wray, J.L. 1977, Calcareous algae. Elsevier, Amsterdam, $185 \mathrm{p}$. 

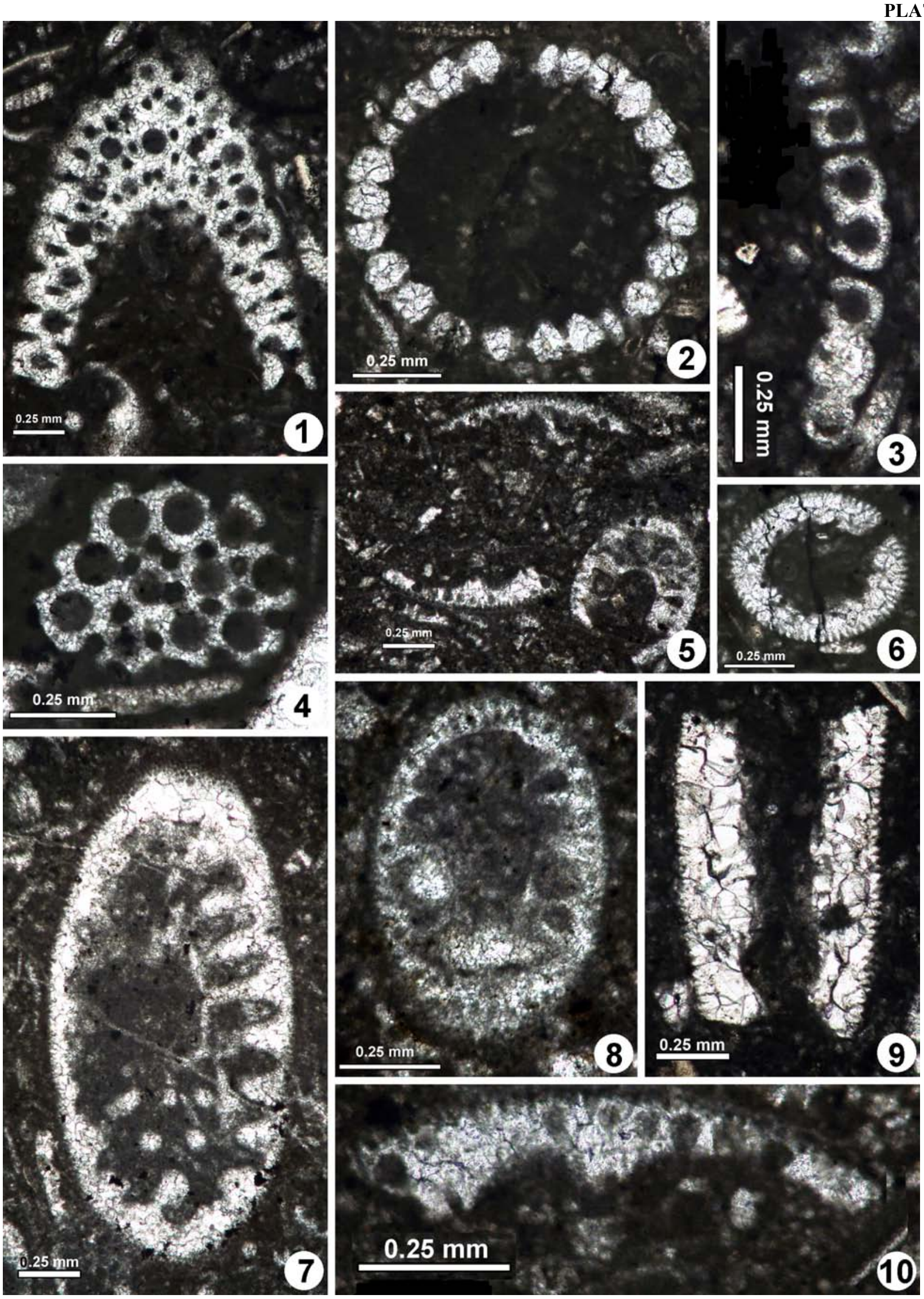

Plate 1. Dasycladalean algae from the lower Upper Cenomanian of the Galala Formation.

Figs. 1-4. Neomeris mokragorensis RADOIČIĆ \& SCHLAGINTWEIT, 2007. Oblique (1), transverse (2), longitudinal-oblique (3), and tangential (4) sections. 1, 3, 4 - thin section 080217-3; 2 - thin section 80217-6.

Figs. 5, 7, 8, 10. Trinocladus divnae RADOIČIĆ, 2006. Oblique $(5,7,8)$, and transverse (5) sections. 10 - close-up view of the specimen in Fig. 5 (lower left part). Thin section 80217-16.

Figs. 6, 9. ?Trinocladus sp. (strongly recystallized specimens). Thin section 80217-6. 


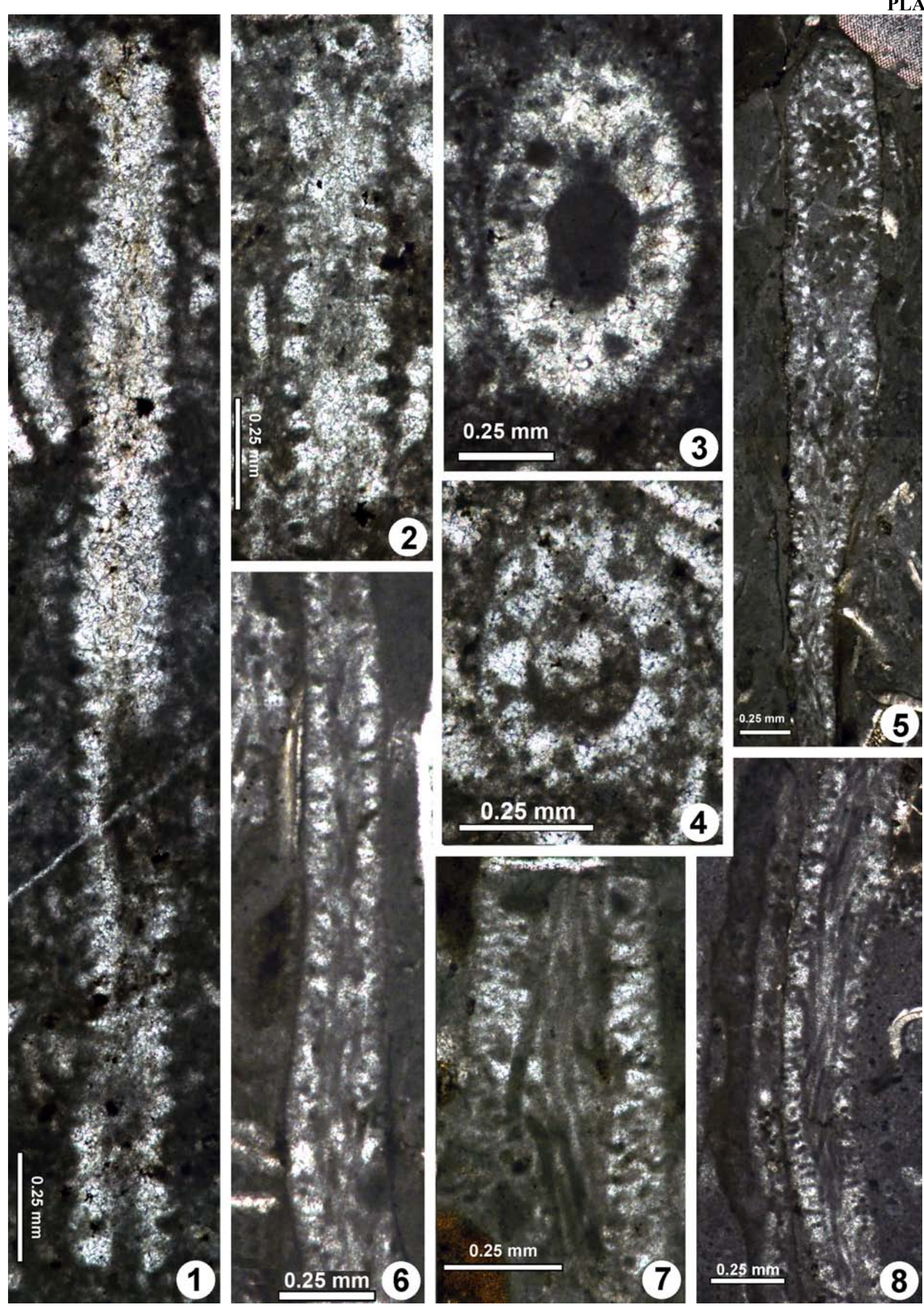

Plate 2. Dasycladalean and halimedacean algae from the lower Upper Cenomanian of the Galala Formation (Figs. 1-4) and upper Lower Turonian of the Magra el Hadida Formation (Figs. 5-8).

Figs. 1, 2. Salpingoporella milovanovici RADOIČIĆ, 1978. Longitudinal, slightly oblique sections. Thin section 80217-16.

Fig. 3. Trinocladus cf. radoicicae ELLIOTT, 1968. Oblique section. Thin section 80217-16.

Fig. 4. Dissocladella sp.. Transverse-oblique section. Thin section 80217-16.

Figs. 5-8. Halimeda cf. elliotti CONARD \& RIOULT, 1977. Random longitudinal-oblique sections through segments. Thin section $80217-29$. 